\title{
Denitrification in the hypolimnion of permanently ice-covered Lake Bonney, Antarctica
}

\author{
B. B. Ward ${ }^{1, *}$, J. Granger ${ }^{1,4}$, M. T. Maldonado ${ }^{2,4}$, K. L. Casciotti ${ }^{1,5}$, S. Harris ${ }^{3}$, \\ M. L. Wells ${ }^{2}$ \\ ${ }^{1}$ Geosciences Department, Princeton University, Princeton, New Jersey 08544, USA \\ ${ }^{2}$ School of Marine Sciences, University of Maine, Orono, Maine 04469, USA \\ ${ }^{3}$ Mother of Mercy High School, Cincinnati, Ohio, USA \\ ${ }^{4}$ Present address: Department of Earth and Ocean Sciences, University of British Columbia, 6270 University Blvd., \\ Vancouver, British Columbia V6T 1Z4, Canada \\ ${ }^{5}$ Present address: Woods Hole Oceanographic Institution, 360 Woods Hole Road, Woods Hole, Massachusetts 02543, USA
}

\begin{abstract}
The distribution of denitrification was investigated in the hypolimnion of the east and west lobes of permanently ice-covered Lake Bonney, Taylor Valley, Antarctica. Anomalously high concentrations of dissolved inorganic nitrogen (DIN; nitrate, nitrite, ammonium and nitrous oxide) in the oxygen-depleted hypolimnion of the east lobe of the Lake implied that denitrification is or was active in the west, but not in the east lobe. While previous investigations reported no detectable denitrification in the east lobe, we measured active denitrification in samples from both the east and west lobes. In the west lobe, measured denitrification rates exhibited a maximum at the depth of the chemocline and denitrification was not detectable in either the oxic surface waters or in the deep water where nitrate was absent. In the east lobe, denitrification was detected below the chemocline, at the depths where ammonium, nitrate, nitrite and nitrous oxide are all present at anomalously high levels. Trace metal availability was manipulated in incubation experiments in order to determine whether trace metal toxicity in the east lobe could explain the difference in nitrogen cycling between the 2 lobes. There were no consistent stimulatory effects of metal chelators or nutrient addition on the rate of denitrification in either lobe, so that the mechanisms underlying the unusual $\mathrm{N}$ cycle of the east lobe remain unknown. We conclude that all the ingredients necessary to allow denitrification to occur are present in the east lobe. However, even though denitrification could be detected under certain conditions in incubations, denitrification is inhibited under the in situ conditions of the lake.
\end{abstract}

KEY WORDS: Antarctica $\cdot$ Denitrification $\cdot$ Metal chelators $\cdot$ Trace metals $\cdot$ Bacteria $\cdot$ Lake Bonney

\section{INTRODUCTION}

Lake Bonney is one of several perennially icecovered lakes in the Taylor Valley of east Antarctica. The chemistry of bottom waters differs substantially among the lakes, providing both mysteries and clues as to the origin of the lakes and their unusual biogeochemistries. Lake Bonney is divided into 2 lobes, each about $40 \mathrm{~m}$ deep, which are connected by a narrow shallow sill (12 to $13 \mathrm{~m}$ ) that effectively separates the deep waters of each basin below the chemocline. The surface waters of the 2 lobes are able to exchange, and the circulation has been described as a set of linked gyres (Priscu \& Spigel 1998). Water enters the system at the foot of the Taylor glacier in the west lobe and via small glacial melt streams into both lobes, and is lost through ablation and sublimation of the ice surface. The hypolimnion in both lobes is hyper-saline, although the relative concentrations of major ions differ considerably between the lobes. Lyons et al. (2000) interpreted the distribution of major elements in the lakes and streams as suggesting different histories 
for the 2 lobes. This history probably involves periods of net evaporation and shrinkage of the east lobe that affected the west lobe to a lesser extent, thus explaining the different ion distributions in the deep water of 2 lobes of the same lake.

The surface water of both lobes is well oxygenated, even supersaturated, due to cryoconentration of stream water as it freezes to the bottom of the ice cover (Craig et al. 1992). Fixed nitrogen is detectable at low levels in the epilimnion. The water below the chemocline depth in both lobes of Lake Bonney is suboxic, and early reports documented high concentrations of bioactive and other trace metals in the hypolimnion (Boswell et al. 1967a,b, Weand et al. 1976). The most striking difference in the chemistry of the deep water is in the concentration and distribution of inorganic nitrogen species (Priscu 1995, Lyons et al. 2000). Based on measurements of chemical species and computed Eh values, Lee et al. (2004) concluded that the 2 lobes differed significantly in redox status, and Priscu et al. (1996) had previously shown a difference in apparent oxygen utilization, the east lobe being less reducing, with smaller apparent oxygen utilization (AOU) values. This difference in redox level is consistent with preliminary reports of trace metal distributions (Wells et al. unpubl. data), which show systematic differences between the lobes.

In the west lobe of Lake Bonney, the chemocline occurs at about 15 to $17 \mathrm{~m}$ and oxygen is depleted below that depth. Ammonium accumulates to a maximum of nearly $300 \mu \mathrm{M}$ in the deep water and nitrate and nitrite both show small maxima (25 and $<1 \mu \mathrm{M}$, respectively) in the region of the chemocline. Nitrous oxide is present at relatively low levels, again with a small maximum (about $1 \mu \mathrm{M}$ ) near the chemocline (Priscu et al. 1996, Voytek et al. 1999). In the east lobe, oxygen is depleted below 18 to $20 \mathrm{~m}$ and ammonium accumulates to a maximum of $>125 \mu \mathrm{M}$ in the deep water. There is a peak in oxygen concentration in the bottom waters of the east lobe, which has yet to be explained. In contrast to the west lobe, however, nitrate and nitrite both accumulate in the deep water of the east lobe, reaching maximum total concentrations of nearly 200 and $40 \mu \mathrm{M}$, respectively. Nitrous oxide reaches a maximum below the chemocline of about $40 \mu \mathrm{M}$, which represents 5800-fold higher concentrations than would be in equilibrium with the atmosphere (Priscu et al. 1996).

Denitrification would be expected to occur in the suboxic conditions in both lobes, leading to depletion of nitrogen oxides. The absence of $\mathrm{NO}_{3}^{-}, \mathrm{NO}_{2}^{-}$, and $\mathrm{N}_{2} \mathrm{O}$ in the hypolimnion of the west lobe, and their presence in the east lobe has been interpreted to infer that denitrification occurs in the west but not in the east lobe. Using an acetylene block method with incubations at in situ temperatures to measure denitrifica- tion, Priscu (1997) detected denitrification at 15 and $20 \mathrm{~m}$ in the west lobe. Very low rates of denitrification at $25 \mathrm{~m}$ in the west lobe could be stimulated by addition of $\mathrm{NO}_{3}{ }^{-}$, which was normally absent at that depth. No denitrification (neither $\mathrm{N}_{2} \mathrm{O}$ consumption nor production) could be detected at 22, 25 or $30 \mathrm{~m}$ in the east lobe (Priscu et al. 1996). Although sulfate is a major ion in both lobes, and oxygen is greatly depleted in the hypolimnion of both lobes, detection of hydrogen sulfide has never been reported for either lobe. This implies that the redox state of the lake is poised at a suboxic state in which denitrification should be favored. Lee et al. (2004) concluded that the redox conditions of the east lobe were not entirely favorable for denitrification, but considerable uncertainty remains about the actual oxygen concentrations (see 'Discussion'), as well as the accuracy of Eh calculations at high salt concentrations.

Phytoplankton primary production is restricted to the layers above the chemocline in both lobes: $22 \mathrm{~m}$ in the east and $20 \mathrm{~m}$ in the west lobe (Priscu 1995, Lizotte et al. 1996). Bacterial abundance and production rates in depth profiles from central stations in both lobes of Lake Bonney show interannual variability, but consistently reach seasonal maxima in November and December (Takacs \& Priscu 1998). In the west lobe, the bacterial abundance maximum (15 to $16 \mathrm{~m}$ ) usually coincides in depth with the productivity maximum, but in the east lobe, a strong abundance maximum at 20 to $25 \mathrm{~m}$ is consistently deeper than the productivity maximum at 12 to $15 \mathrm{~m}$ (Takacs \& Priscu 1998). The productivity data consistently show detectable bacterial activity in and below the chemocline of the west lobe, but more rarely and at very low levels at analogous depths in the east lobe.

The apparent collapse of the nitrogen cycle in the east lobe could thus be specific to some process, i.e. denitrification, in the nitrogen cycle itself, or it could be due to overall limitation, toxicity or inhibition of essentially all microbial activity in the water. Although thymidine incorporation rates were very low below $19 \mathrm{~m}$ in the east lobe, the lake is not in fact completely devoid of biological activity. In an extensive set of incubation experiments, we made multiple measurements of thymidine incorporation rates in subchemocline waters of the east lobe (Ward et al. 2003). Very low rates of bacterial production could be detected, but no combination of manipulations such as organic carbon or phosphorus additions, dilution of the salt and metal content and chelation of bioactive metals in the deep water significantly enhanced production rates in the hypolimnion samples. Herein, we report a similar set of incubation experiments designed to detect denitrification in the lake and to investigate the potential for manipulations of water chemistry to alter the observed rates. 


\section{MATERIALS AND METHODS}

Sample collection and incubation. Samples were collected in November and December of 1999 and 2000. Water was collected from a central station in each lobe of Lake Bonney using trace metal clean sampling techniques (Bruland et al. 1979) as described previously (Ward et al. 2003). Briefly, a peristaltic pump equipped with acid-leached C-Flex tubing (Cole Parmer) was used to pump water from depth through an acid-cleaned teflon tube which was lowered through a hole drilled through the $4 \mathrm{~m}$ thick permanent ice cover. Sampling always proceeded from shallow to deeper depths to avoid contaminating the tubing with the higher salt and metal content of the deeper layers. At each depth, $10 \mathrm{l}$ of water (approximately 3 tubing volumes) was pumped and discarded in order to rinse the tubing between samples. Sampling depth was determined by means of a line (weighted with a sealed $4 \mathrm{l}$ plastic bottle filled with sand) previously marked in $0.5 \mathrm{~m}$ intervals, to which the sampling tubing was firmly attached. Depths are relative to the surface of the water (the hydrostatic water depth, which was approximately $1 \mathrm{~m}$ below the ice surface). This is not the most precise way to measure depth, but based on the chemical distributions (see 'Results'), it appears to have been reproducible and succeeded in preventing metal contamination associated with more precise measurement instruments.

Polyethylene-lined trilaminate bags (Pollution Measurement Corporation) were used for sample collection and incubation (Ward et al. 2003). Bags were acidwashed and flushed with $\mathrm{N}_{2}$ gas prior to use. The sample tubing passed through a debubbler to avoid collecting a headspace in the incubation bags. Most of the gas lost in the debubbler was excess $\mathrm{CO}_{2}$, but other gases were unavoidably stripped in the process. Nitrous oxide concentrations measured in the bags were lower than those reported from similar depths previously, but direct concentration comparisons between bottle-collected samples and debubbled samples were not made. Water exited the sampling tube inside a Plexiglas, positive pressure hood supplied with HEPA-filtered air. The water was pumped directly into trilaminate bags (either $500 \mathrm{ml}$ or $10 \mathrm{l}$ maximum volume) through the bag openings, which were of hard polypropylene tubing, $10 \mathrm{~cm}$ in length and of 0.312 or $0.625 \mathrm{~cm}$ diameter, respectively. The bags were closed with plastic 3-way stopcocks, and placed in insulated boxes for return to the laboratory by helicopter (maximum $4 \mathrm{~h}$ ).

Experimental manipulation. In the laboratory, the bags were weighed and sample masses in the $500 \mathrm{ml}$ bags were all set to $400 \mathrm{~g}$ (approx. $400 \mathrm{ml}$ ) by removing any excess water with an acid-cleaned syringe. The larger bags were weighed and all additions were scaled to the weight. Bags were incubated in a $12^{\circ} \mathrm{C}$ dark incubator (previous work had determined that $12^{\circ} \mathrm{C}$ was the optimal growth temperature for several denitrifying cultures isolated from this lake; Ward \& Priscu 1997). After equilibration to incubation temperature (usually overnight), additions were made to the bags to effect various treatments. All solutions were made up in Milli-Q water and were subsequently treated with Chelex (Price et al. 1988/1989) and all additions were made with acid-cleaned plastic syringes.

Detection of denitrification depended on the assumption that acetylene completely blocks the activity of nitrous oxide reductase, the last enzyme in the complete denitrification sequence, thus allowing $\mathrm{N}_{2} \mathrm{O}$ to accumulate at a rate equivalent to the overall denitrification rate. Similar acetylene block experiments were performed in 1999 and 2000, but with important differences in replication, duration and analytical details. In 1999, incubations were performed in $500 \mathrm{ml}$ bags. Acetylene and various chelators, and other treatments (see Table 1 and below) were added directly to these bags, which were incubated for up to $10 \mathrm{~d}$. For denitrification rate measurements, $200 \mathrm{ml}$ acetylene was added to $400 \mathrm{ml}$ samples in experimental bags (no acetylene was added to a control bag), and the bags were shaken vigorously to dissolve the acetylene. For the depth profiles in 1999, 3 bags were incubated for each depth: 2 bags received acetylene, 1 bag did not. For other experiments in which several treatments were performed on water from the same depth, each treatment was performed in duplicate, but 1 set of duplicate controls without acetylene was applied to the entire experiment.

The acetylene went into solution in samples from above the chemocline, but a headspace usually remained in the samples from deeper water, due to decreased solubility of acetylene at higher ionic strengths. The bags were allowed to equilibrate overnight and any headspace was then removed. Small bags were subsampled for $\mathrm{N}_{2} \mathrm{O}$ assays 4 or 5 times during the incubation by withdrawing $40 \mathrm{ml}$ of water into a $50 \mathrm{ml}$ syringe flushed with $\mathrm{N}_{2} . \mathrm{N}_{2}(10 \mathrm{ml})$ was drawn into the syringe, and the water was equilibrated into the headspace by shaking for $2 \mathrm{~min}$. The headspace was injected into a previously evacuated $10 \mathrm{ml}$ serum vial containing $1 \mathrm{ml}$ of $2 \mathrm{~N} \mathrm{KCl}$. This procedure was repeated with each subsample to achieve a multiple equilibration. The vials were stored upside down (up to a few days) until analysis.

In 2000, 2 manipulation experiments (BB 2 and BB 3) were carried out in which various chelators or substrates were added to duplicate 101 bags. The acetyl- 
ene block incubations, however, were carried out in $500 \mathrm{ml}$ bags, which were filled in triplicate from the larger bags. In this way, the treatment incubations in the large bags continued for up to $3 \mathrm{wk}$, but denitrification rate measurements in the small bags were made on much shorter time scales. Results from the 1999 experiments suggested that exposure to acetylene was detrimental to the overall bacterial community activity, and even where denitrification was detected, the rates were usually not linear beyond 4 to $6 \mathrm{~d}$. Long-term incubations in large bags and shorter-term rate measurements in smaller bags avoided this problem.

For denitrification rate measurements from the large bag experiments, three $500 \mathrm{ml}$ bags were filled from each of 2 replicate 101 treatment bags; 2 of the 3 small bags received acetylene and 1 did not. The small bags were allowed to equilibrate overnight after acetylene addition and any headspace was then removed. $\mathrm{N}_{2} \mathrm{O}$ was sampled from each of the small bags 2 or 3 times over the incubation as described above, except that 3 instead of 2 equilibrations were done.

$\mathrm{N}_{2} \mathrm{O}$ was assayed using a Hewlett Packard HP5890 Series II gas chromatograph with an electron capture detector and 2 parallel 2 m columns packed with Haysep D (80/100 mesh). The columns were heated to about $65^{\circ} \mathrm{C}$ and the detector was run at $250^{\circ} \mathrm{C}$. Duplicate $1 \mathrm{ml}$ subsamples from each vial, containing a headspace sample, were assayed using a calibrated sample loop. $\mathrm{N}_{2} \mathrm{O}$ concentration in the original sample was calculated from the 2 or 3 serial equilibration samples using the multiphase equilibrium approach (Byrne \& Nicholas 1986). The $\mathrm{R}^{2}$ for the regression of peak area vs. extraction number averaged 0.988 (SD = $0.014)$ to 0.994 ( $\mathrm{SD}=-0.007$ ) for individual time points ( $\mathrm{n}=20$ to 30 sets of 2 equilibrations at each time point in 1999; $\mathrm{n}=30$ sets of 3 equilibrations at each time point in 2000). Most of the variability in the results arose from differences between incubation bags (see below), rather than between duplicate measurements.

Denitrification rates (in terms of $\mathrm{N}_{2} \mathrm{O}$ accumulation rates) were computed from the linear regression of $\mathrm{N}_{2} \mathrm{O}$ concentration vs. incubation time, after $\mathrm{N}_{2} \mathrm{O}$ concentration in the no-acetylene bag had been subtracted from the $\mathrm{N}_{2} \mathrm{O}$ concentrations measured in the bags to which acetylene had been added. A rate is considered significantly greater than zero if the $95 \%$ confidence interval (CI) around the slope does not include zero. Slope and CI were calculated according to the least squares regression method (Snedecor \& Cochran 1967).

Treatments applied to the incubations. Control incubations: The first experiment in each lobe of the lake was a control experiment designed to explore the depth distribution of denitrification in each lobe (performed in 1999). For each depth, three $500 \mathrm{ml}$ bags were incubated, 2 of which received acetylene and 1 that did not. All bags were incubated at $12^{\circ} \mathrm{C}$ and sampled 5 times over $7 \mathrm{~d}$.

Chelators: Reagent grade desferrioxamine B (DFB; 1 to $5 \mu \mathrm{M})$, diethylenetriaminepentaacetic acid (DTPA; 0.75 to $100 \mu \mathrm{M}$ ), diethyldithiocarbamate (DDC; 10 to $100 \mu \mathrm{M})$, and humic acid (HA; Sigma; $32 \mathrm{mg} \mathrm{l}^{-1}$ ) were added at various concentrations to separate treatments (concentrations given in 'Results' where appropriate). DFB is a siderophore isolated from terrestrial fungus that is strongly specific for iron. At least 1 marine bacterium has been found to produce desferrioxamine D, which is structurally very similar to DFB (Martinez et al. 2001) and other marine strains are capable of utilizing iron bound by DFB (Granger \& Price 1999). DFB was used here to manipulate the chemical speciation of iron in various treatments. DDC is somewhat preferential for copper and is often used to chelate copper when testing for its requirement in enzymes (e.g. Coyne et al. 1989). In contrast, DTPA is a more general synthetic metal chelator having differing affinities for a range of bioactive metals. DTPA was chosen over EDTA because of its reduced side reactions with $\mathrm{Ca}^{++}$ and $\mathrm{Mg}^{++}$, thus allowing it to bind the metals more efficiently than EDTA in this superhaline water. HA comprises natural compounds having comparatively low affinities for trace metals in high ionic strength media. If some of the metals are present at toxic levels, then chelation might reduce their biological activity and thus allow growth and/or denitrification.

Organic substrates: Bactopeptone (B, $200 \mathrm{mg} \mathrm{l}^{-1}$, the level used for cultivation of lake isolates in Chelexed medium) was added to some treatments. Additions of organic carbon had been found to increase denitrification rates in the west lobe of Lake Bonney (Priscu 1997). If carbon substrate concentrations were limiting to bacterial growth, then additional substrate might enhance growth and/or denitrification.

Inorganic nutrients: Nitrate $(50 \mu \mathrm{M}$; about the level observed at $19 \mathrm{~m}$ in the east lobe) was added to circumvent potential limitation of denitrification by nitrate in dilution experiments (see next paragraph), assuming that most cells present in the suboxic water would be capable of denitrification.

Dilution experiments (1999 only): For these experiments, lake water was collected using the clean pumping set up as described in a subsection above, but the water was collected in a 201 carboy (acid-cleaned), filled to overflowing and sealed for transport to the laboratory. In the $4^{\circ} \mathrm{C}$ room in a glove box flushed with $\mathrm{N}_{2}$, the water was diluted in a large beaker with appropriate amounts of either Milli-Q water or artificial lake water (Ward et al. 2003) that had also been flushed with $\mathrm{N}_{2}$, and then pumped into the $500 \mathrm{ml}$ incubation bags using a small peristaltic pump. Dilution with artificial lake water was designed to remove the metal compo- 
nent of the solutes without changing the salinity, which was approximately 80 at the chemocline depth of the east lobe. Dilution with Milli-Q water was intended to dilute both metals and salts, thus reducing potential metal toxicity and providing a salinity closer to that determined previously as optimal for growth of denitrifiers isolated from Lake Bonney (Ward \& Priscu 1997).

Live bacterial cultures (CB): Denitrifying bacterial strains previously isolated from Lake Bonney (Ward \& Priscu 1997) were cultured at $12^{\circ} \mathrm{C}$ in trace metal clean conditions in the laboratory in the same kind of bags used for experimental incubations. Cells were grown in artificial seawater medium (35) following a recipe described previously (Granger \& Price 1999), amended with $250 \mu \mathrm{M}$ nitrate. Metal concentrations were buffered with $100 \mu \mathrm{M}$ EDTA. Cultured bacteria were added to the treatment bags at a final concentrations ranging from $5 \times 10^{4}$ to $10^{5} \mathrm{ml}^{-1}$. The inoculum consisted of approximately equal numbers of the 2 denitrifying strains ELB17 and WBL20, which had been isolated from the east lobe and west lobe of Lake Bonney, respectively, in 1992. The abundance of CB in the experimental incubations was determined by indirect immunofluorescence staining and epifluorescence microscopy (see next subsection; Ward \& Priscu 1997) of subsamples collected from the bags. If the addition of live bacteria to the experimental bags caused an increase in the denitrification rate, it would imply that the lake water was not completely inhibitory to denitrification, even if denitrification could not be detected in unamended samples.

Chemical and microbiological analyses. Oxygen concentrations in the incubation bags were measured using the micro-Winkler colorimetric method (Broenkow \& Cline 1969) and nitrite by the azo-dye colorimetric method (Parsons et al. 1984). In 1999, oxygen measurements were made for duplicate $500 \mathrm{ml}$ bags that were incubated in parallel to monitor for leakage. In 2000, individual $10 \mathrm{l}$ bags were subsampled for oxygen measurements periodically. No significant increases in oxygen concentration were detected in any large bags measured for up to $2 \mathrm{wk}$, but it cannot be guaranteed that none of the actual small incubation bags leaked. Indirect immunofluorescence (IIF) enumeration of the cultivated Lake Bonney denitrifying strains was performed as described previously (Ward \& Carlucci 1985, Ward \& Priscu 1997). Samples were viewed by epifluorescence microscopy at $1000 \times$ power using a Zeiss standard microscope with epifluorescence modification (50 W Hg illumination; 450 DF 55 filter for excitation, $505 \mathrm{DF} 35$ barrier filter and 505DRLEXT02 dichroic filter). Acridine orange stained filters were prepared from 5 to $10 \mathrm{ml}$ aliquots of the samples and enumerated using the same microscope with the same filter set (AODC, Hobbie et al. 1977).

\section{RESULTS}

\section{Nutrient and metal distributions}

The depth distributions of nutrients and hydrographic variables for the stations and experiments sampled here have been reported previously (Ward et al. 2003). Detailed major element, DIC and $\mathrm{pH}$ data can be found on the web page maintained by the McMurdo LTER team (http://huey.colorado.edu/LTER, hereafter referred to as LTER). The dissolved inorganic nitrogen (DIN) and oxygen distributions provided the context for our choice of sampling depths, so they will be described briefly. DIN (comprising ammonium, nitrite and nitrate) and phosphate were depleted in the epilimnion of both lobes, which was defined by a strong halocline (15 to $20 \mathrm{~m}$ in the east and 13 to $15 \mathrm{~m}$ in the west lobe). The surface waters were essentially fresh, while the deep waters were on the order of 5- to 10 -fold saltier than seawater, albeit with different ionic compositions. The concentration of all 3 DIN components in the east lobe increased from approximately $15 \mathrm{~m}$ to 30-35 $\mathrm{m}$, where maximum levels were observed: $\left[\mathrm{NH}_{4}{ }^{+}\right]$maximum of $129 \mu \mathrm{M}$ at $35 \mathrm{~m}$; $\left[\mathrm{NO}_{2}{ }^{-}\right]$ $50 \mu \mathrm{M}$ at $30 \mathrm{~m} ;\left[\mathrm{NO}_{3}{ }^{-}\right] 179 \mu \mathrm{M}$ at $30 \mathrm{~m}$. In the west lobe, nitrite was detectable only at trace levels (never more than $0.43 \mu \mathrm{M}) ; \mathrm{NO}_{3}{ }^{-}$was present at a maximum of $24 \mu \mathrm{M}$ at $19 \mathrm{~m}$ and was not detectable below $22 \mathrm{~m}$, while ammonium reached a maximum of $264 \mu \mathrm{M}$ at $35 \mathrm{~m}$. The in situ temperature exhibited a subsurface maximum of $5.8^{\circ} \mathrm{C}$ in the east lobe at $15 \mathrm{~m}$ and $2.3^{\circ} \mathrm{C}$ at $5.3 \mathrm{~m}$ in the west lobe; minimum temperatures were -2 and $-4^{\circ} \mathrm{C}$ in the bottom waters of the east and west lobes, respectively.

Oxygen concentrations have been measured routinely by the LTER team and were reported for these stations previously (Ward \& Priscu 1997). An extensive time series of $\left[\mathrm{O}_{2}\right]$ appears on the LTER website. Although precise $\mathrm{O}_{2}$ measurements throughout the low oxygen depth range have not been routinely made, available data indicated that the hypolimnion was suboxic and it was always assumed that $\left[\mathrm{O}_{2}\right]$ was low enough to allow denitrification to occur; this assumption and the supporting data are examined in the 'Discussion'. The oxycline coincides essentially with the nutricline; $\left[\mathrm{O}_{2}\right]$ reached its minimum value at $22 \mathrm{~m}$ in the east and $18 \mathrm{~m}$ in the west lobe. A slight increase above the minimum $\left[\mathrm{O}_{2}\right]$ of the hypolimnion has been reported in the 37 to $40 \mathrm{~m}$ interval in the east lobe (Ward \& Priscu 1997; LTER website).

Complete metal concentration and speciation data will be reported in detail elsewhere (Wells et al. unpubl.). Preliminary data have been published previously (Ward et al. 2003) and are briefly summarized here: total dissolved metals were uniformly low in the surface waters 
of both lobes, in the low nM range for $\mathrm{Mo}, \mathrm{Cd}, \mathrm{Pb}, \mathrm{Mn}$, $\mathrm{Fe}, \mathrm{Co}, \mathrm{Ni}, \mathrm{Cu}$ and $\mathrm{Zn}$. Concentrations of all these elements increased dramatically below the chemocline in both lobes. Most metals had maximum concentrations (in the $1000 \mathrm{nM}$ range, except for $\mathrm{Mn}$, which reached 80 and $164 \mu \mathrm{M}$ in the east and west lobes, respectively, and $\mathrm{Fe}$, which was $55 \mu \mathrm{M}$ in the west lobe) at $25 \mathrm{~m}$ in the east lobe and at $35 \mathrm{~m}$ in the west lobe. Some metals, including $\mathrm{Fe}, \mathrm{Mn}, \mathrm{Cu}$ and $\mathrm{Co}$ were present in the west lobe at higher concentrations than in the east, which suggests that if metal toxicity is a factor controlling $\mathrm{N}$ cycling, then metal ratios or interactions may be more important than concentrations alone.

\section{Depth profiles of denitrification in the west and east lobes}

The depth distribution of denitrification was measured in 1 profile from each lobe in 1999. A distinct maximum in the denitrification rate was observed at 16 $\mathrm{m}$ in the west lobe $\left(0.733 \pm 0.383 \mathrm{nM} \mathrm{N}_{2} \mathrm{O} \mathrm{h}^{-1}\right.$; slope of the time course regression line $\pm 95 \% \mathrm{CI}$ around the slope) (Fig. 1a). Rates significantly greater than zero (at the $95 \%$ confidence level) were detected at 13, 16 and $19 \mathrm{~m}$, but not deeper or shallower (Fig. 1a).
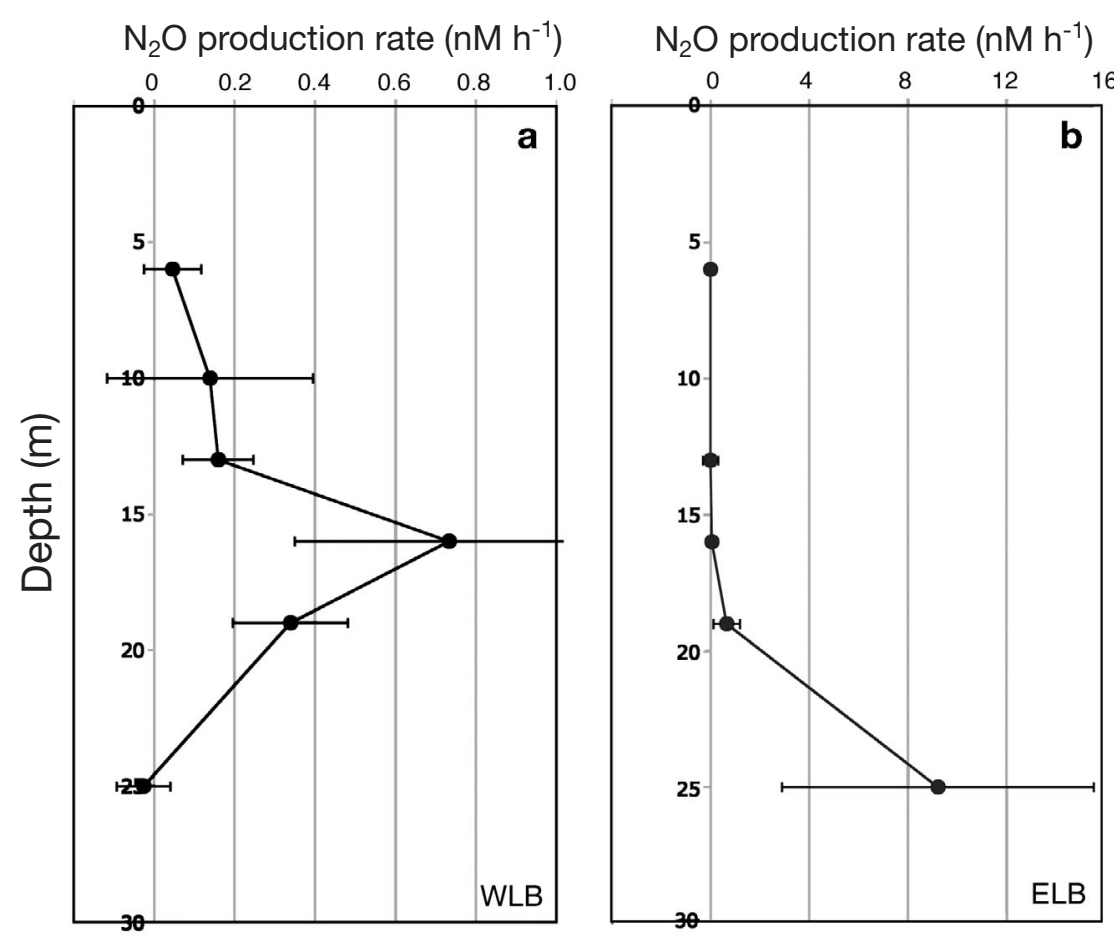

Fig. 1. Depth distribution of $\mathrm{N}_{2} \mathrm{O}$ accumulation rate in (a) the west lobe (WLB) and (b) the east lobe (ELB) in 1999, showing change in $\left[\mathrm{N}_{2} \mathrm{O}\right]$ slope with time. Data represent 2 small bags which received acetylene minus no addition control; error bars represent $95 \%$ confidence intervals on the slope
In the east lobe, a significant production rate of $\mathrm{N}_{2} \mathrm{O}$ was detected at both 19 and $25 \mathrm{~m}$, although the $95 \%$ confidence intervals were quite large (Fig. 1b). The maximum rate $\left(9.22 \pm 6.32 \mathrm{nM} \mathrm{N}_{2} \mathrm{O} \mathrm{h}^{-1}\right)$, measured at $25 \mathrm{~m}$, was an order of magnitude greater than that observed in the west lobe.

\section{Trace metal and nutrient manipulations}

Experiments in small bags

All these experiments were performed on water collected from the east lobe. In 1999, the water was collected from 19 or $22 \mathrm{~m}$, because the hyrographic data implied this interval in the east lobe might be analogous to 15-16 $\mathrm{m}$ in the west lobe, which was the depth at which we expected to find significant denitrification. The treatments that were performed in numerous experiments on several dates are listed in Table 1. Rates were calculated as the slope of $\mathrm{N}_{2} \mathrm{O}$ concentration over time on the basis of 4 time points taken over a period of up to $12 \mathrm{~d}$. Within each experiment, all treatments were duplicated ( 2 experimental bags and 1 control bag per treatment) and duplicates were combined for calculation of slope and CI.

The only experiments which yielded denitrification rates significantly greater than zero (i.e. the $95 \%$ CI for slopes computed from replicates did not intersect zero) were 4 treatments in an experiment in which some samples were diluted and others were filtered or received additions of cultured bacteria (Fig. 2; all treatments shown here had significant $\mathrm{N}_{2} \mathrm{O}$ accumulation rates, i.e. greater than zero, although none were significantly different from the others). The $100 \%$ incubation (i.e. no dilution, the control, shown in Fig. 2 for comparison) is the $19 \mathrm{~m}$ measurement from the depth profile experiment above (no additions other than acetylene to 2 of the bags). Although the 95\% CI does not quite include zero, the error around the slope is large. Experimental samples that were diluted 2-fold $(50 \%$ lake water) and 10-fold (10\% lake water) with Milli-Q water showed slopes greater than zero. If the measured rates in the diluted samples are multiplied by their respective dilution factors (i.e. normalized to the bacterial concentration of the control sample), the rates (0.54 and $0.77 \mathrm{nM} \mathrm{h}^{-1}$ ) are indistinguishable from 
Table 1. Experiments and treatments with water from the east lobe of Lake Bonney. Dilution: \% lake water; CB: cultured bacteria. -: not added; ALW: artifical lake water; B: bactopeptone; DDC: diethydithiocarbamate; DFB: desferrioxamine $B_{i}$ DTPA: diethylenetriaminepentaacetic acid; F: $0.2 \mu \mathrm{M}$ filtered lake water; HA: humic acids, $32 \mathrm{mg} \mathrm{l}^{-1}$

\begin{tabular}{|c|c|c|c|c|c|}
\hline \multirow{2}{*}{$\begin{array}{l}\text { Year } \\
\text { Expt }\end{array}$} & \multirow{2}{*}{$\begin{array}{l}\text { Bag } \\
\text { no. }\end{array}$} & \multicolumn{4}{|c|}{ - Treatment } \\
\hline & & Dilution (\%) & CB & Chelator & Other \\
\hline \multicolumn{6}{|l|}{1999 (500 ml bags) } \\
\hline \multirow[t]{6}{*}{ Dilution (19 m) } & 1,2 & 50 & - & - & ALW \\
\hline & 3,4 & 10 & - & - & ALW \\
\hline & 5,6 & 100 & + & - & \\
\hline & 7,8 & 50 & + & - & ALW \\
\hline & 9,10 & 10 & + & - & ALW \\
\hline & 11,12 & 100 & + & - & $\mathrm{F}$ \\
\hline \multirow[t]{8}{*}{ Chelator (22 m) } & 1,2 & 100 & - & - & \\
\hline & 3,4 & 100 & + & - & \\
\hline & 5,6 & 100 & - & DTPA $(0.75 \mu \mathrm{M})$ & \\
\hline & 7,8 & 100 & - & DTPA $(7.5 \mu \mathrm{M})$ & \\
\hline & 9,10 & 100 & - & DFB $(1 \mu \mathrm{M})$ & \\
\hline & 11,12 & 100 & + & DTPA $(0.75 \mu \mathrm{M})$ & \\
\hline & 13,14 & 100 & + & DTPA $(7.5 \mu \mathrm{M})$ & \\
\hline & 15,16 & 100 & + & DFB $(1 \mu \mathrm{M})$ & \\
\hline \multirow[t]{8}{*}{ Chelator (19 m) } & 1,2 & 100 & + & - & \\
\hline & 3,4 & 100 & + & DTPA $(7.5 \mu \mathrm{M})$ & \\
\hline & 5,6 & 100 & - & DTPA $(7.5 \mu \mathrm{M})$ & \\
\hline & 7,8 & 100 & + & - & \\
\hline & 9,10 & 100 & & - & ALW \\
\hline & 11,12 & 100 & + & - & \\
\hline & 13,14 & 100 & + & DTPA $(7.5 \mu \mathrm{M})$ & ALW \\
\hline & 15,16 & 100 & + & DTPA $(7.5 \mu \mathrm{M})$ & \\
\hline \multicolumn{6}{|l|}{2000 (10 l bags) } \\
\hline \multirow[t]{5}{*}{ Expt BB $2(23 \mathrm{~m})$} & 1,2 & 100 & & - & \\
\hline & 3,4 & 100 & + & - & $\mathrm{B}$ \\
\hline & 5,6 & 100 & + & DFB $(5 \mu \mathrm{M})$ & $\mathrm{B}$ \\
\hline & 7,8 & 100 & + & DFB $(5 \mu \mathrm{M})$ & \\
\hline & 9,10 & 100 & - & - & \\
\hline \multirow[t]{5}{*}{ Expt BB $3(23 \mathrm{~m})$} & 1,2 & 100 & + & $\mathrm{HA}\left(32 \mathrm{mg} \mathrm{l}^{-1}\right)$ & \\
\hline & 3,4 & 100 & + & $\mathrm{HA}\left(32 \mathrm{mg} \mathrm{l}^{-1}\right)$ & $\mathrm{B}$ \\
\hline & 5,6 & 100 & - & $\mathrm{DFB}(5 \mu \mathrm{M})$ & \\
\hline & 7,8 & 100 & + & $\mathrm{DDC}(10 \mu \mathrm{M})$ & B \\
\hline & 9,10 & 100 & - & - & \\
\hline
\end{tabular}

19 m control, although the uncertainty of each measurement makes such comparisons rather weak. Samples that had been filtered $(0.2 \mu \mathrm{m})$ and then had cultured bacteria added to them $(\mathrm{F}+\mathrm{CB})$ denitrified at the same rate as the control and the treatment in which CB were added to unfiltered 19 m water.

These results (Fig. 2) suggest that (1) the addition of CB to the $100 \%$ lake water did not enhance the rate above that observed with no additions; (2) CB added to filtered $100 \%$ lake water denitrified at a rate comparable to the control; and (3) denitrification rates in the diluted samples were not enhanced by dilution, but were simply diluted out with the dilution of the organisms in the water. Because of the large uncertainty, it cannot be concluded that the addition of $\mathrm{CB}$ to filtered lake water had any effect above $\mathrm{CB}$ alone or no addition, but significant rates of $\mathrm{N}_{2} \mathrm{O}$ accumulation were detected in all treatments.

\section{Experiments in large bags}

The 101 bag incubations exposed the samples to treatment conditions for $20 \mathrm{~d}$, which, even at the low in situ growth rates expected in the lake, might have been sufficient time to induce recovery or new growth of the community. In order to evaluate the consistency of conditions in the incu-

the undiluted treatments (ranging from 0.66 to $0.84 \mathrm{nM}$ $\mathrm{h}^{-1}$ ). Thus, the diluted samples had rates that were essentially proportionate to the rate observed in the bations over this time, nitrite concentration was measured initially and oxygen concentration was measured periodically on subsamples drawn from the 101
Fig. 2. $\mathrm{N}_{2} \mathrm{O}$ accumulation rate in various treatments in an experiment from $19 \mathrm{~m}$ in the east lobe in 1999, showing change in $\left[\mathrm{N}_{2} \mathrm{O}\right]$ slope with time (acetylene treatments minus no addition control); error bars represent $95 \%$ confidence intervals on the slope. $10 \%, 50 \%$ : fractions of natural lake water present in the incubation after dilution with artificial lake water; $100 \%$ : no amendment control; F + CB: natural lake water filtered through $0.2 \mu \mathrm{m}$ cellulose acetate filters with cultivated bacteria added (mixture of Strains ELB17 and WLB20 at a final concentration of $\sim 10^{5}$ cells $\mathrm{ml}^{-1}$ ) ; $100 \%+\mathrm{CB}$ : natural lake water to which the same mixture of cultivated bacteria was added

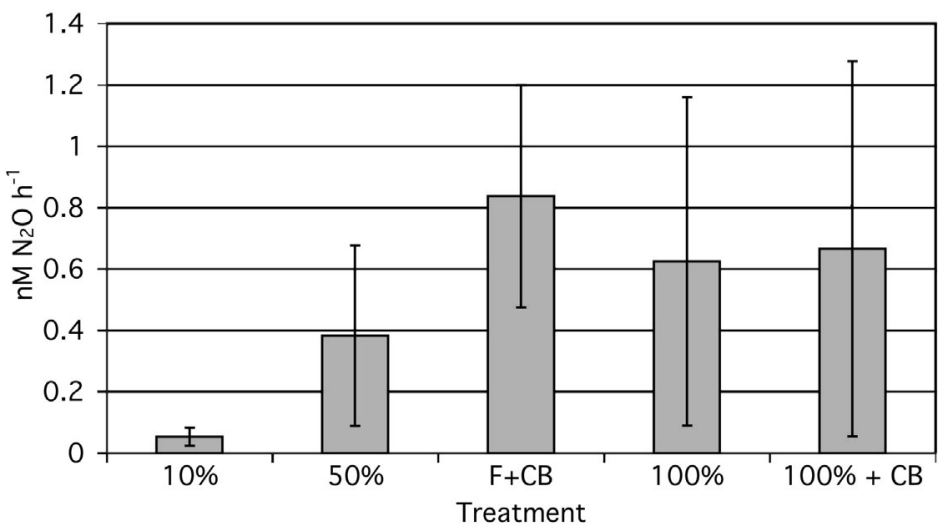


bags. For all 10 bags in Expt BB 2, the average initial $\left[\mathrm{NO}_{2}{ }^{-}\right]$was $8.2 \mu \mathrm{M}(\mathrm{SD}=0.4 \mu \mathrm{M})$, and for Expt BB 3, the average initial $\left[\mathrm{NO}_{2}^{-}\right]$was $8.3 \pm 0.5 \mu \mathrm{M}$. Thus it is clear that the same depth was sampled for both of these experiments, and in comparison with discrete DIN samples, this $\left[\mathrm{NO}_{2}^{-}\right]$is consistent with the target sampling depth of $23 \mathrm{~m}$.

The average initial $\left[\mathrm{O}_{2}\right]$ was more variable among incubation bags, probably due to the awkwardness of sampling from the bags without atmospheric contamination. The average initial $\left[\mathrm{O}_{2}\right]$ for the ten $10 \mathrm{l}$ bags in BB 2 was $34.5 \pm 5.5 \mu \mathrm{M}$, while for BB 3 it was $31.5 \pm 5.0 \mu \mathrm{M}$. A subset of the bags in both experiments was sampled for $\left[\mathrm{O}_{2}\right]$ at 5 or 7 , and 13 or $15 \mathrm{~d}$ for BB 2 and BB 3, respectively. The average of all these samples was not significantly different from the initial values (Fig. 3). Thus it appears that (1) the bags did not leak during the course of the incubation, and (2) both sets of incubations behaved similarly in terms of initial conditions and lack of variation throughout the incubations.

In 2000, $\mathrm{N}_{2} \mathrm{O}$ accumulation was measured 3 times during the course of 5 to $7 \mathrm{~d}$ in triplicate small (500 ml) bags containing subsamples from the $10 \mathrm{l}$ treatment bags. In Fig. 4, the height of each bar represents the average rate of $\mathrm{N}_{2} \mathrm{O}$ accumulation (or disappearance) in each set of replicate small bags (rate computed from $\left[\mathrm{N}_{2} \mathrm{O}\right]$ in the 2 bags after subtracting the $\left[\mathrm{N}_{2} \mathrm{O}\right]$ in the no-acetylene bag). The error bars represent the range of 2 replicate small bags from each large bag. Despite

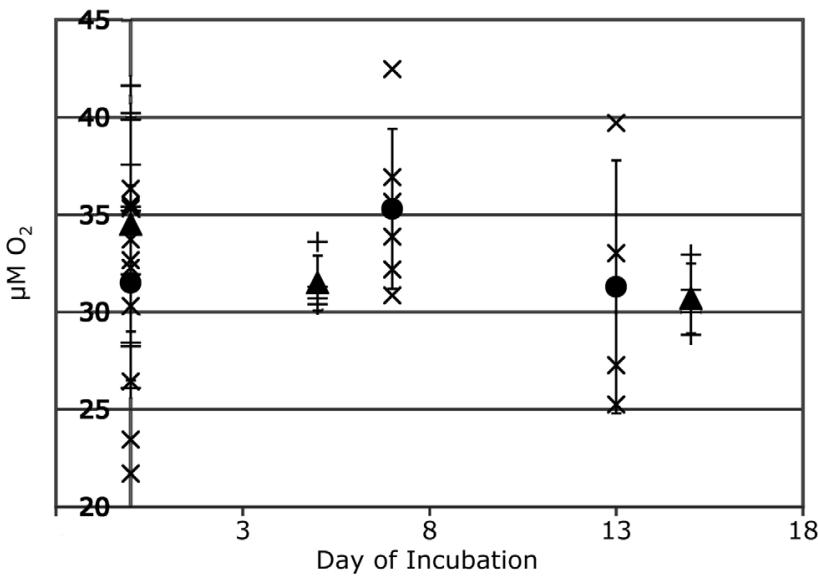

Fig. 3. $\left[\mathrm{O}_{2}\right]$ in the $10 \mathrm{l}$ bag experiments in 2000 based on microcolorimetric assays. Oxygen concentrations were measured on samples from all the large bags on Day 0 and on a subset of the large bags in Expt BB 2 on Days 5 and 15 and in Expt BB 3 on Days 7 and 13. Individual measurements (mean of 2 replicates per large bag) are plotted: (+) Expt BB 2; (X) Expt BB 3. Error bars represent standard deviation around the mean of all measurements on each day: $(\mathbf{\Delta})$ Expt BB 2;

(๑) Expt BB 3
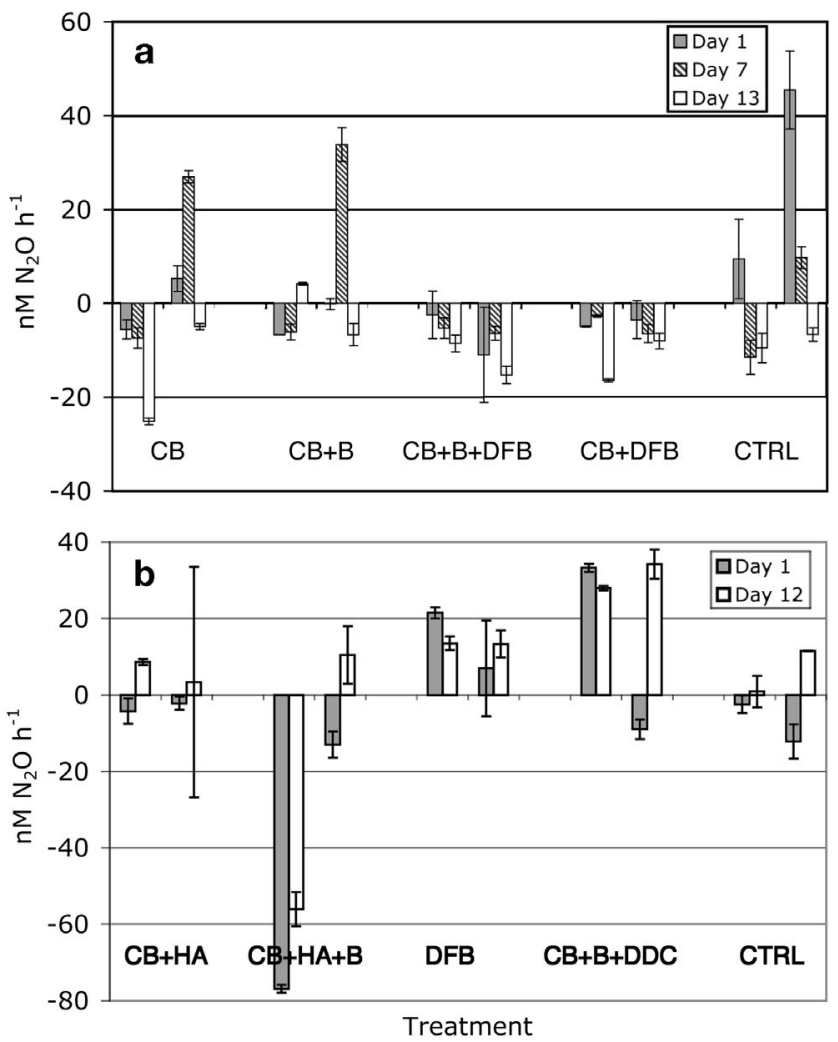

Fig. 4. $\mathrm{N}_{2} \mathrm{O}$ accumulation rate in (a) Expt BB 2 and (b) Expt BB 3 in 2000 with water collected from $23 \mathrm{~m}$ in the east lobe. Height of bars represents change in average $\left[\mathrm{N}_{2} \mathrm{O}\right]$ slope with time in individual small incubation bags subsampled from the $10 \mathrm{l}$ treatment bags. Error bars represent the range of replicate slopes (insufficient data to compute a confidence interval). See Table 1 for treatment codes. CTRL: control, i.e. no addition

the large number of $\left[\mathrm{N}_{2} \mathrm{O}\right]$ measurements made during the course of these experiments, there were only 2 replicate small bags for each large bag, so it is not possible to compute standard deviations. Whenever the error bars do not intersect zero, the change in $\left[\mathrm{N}_{2} \mathrm{O}\right]$ in the replicate small bags was in the same direction.

In general, duplicate small bags subsampled from a single 101 bag behaved similarly. For example, two 101 bags were incubated without any treatment (control; CTRL in Fig. 4a) and both CTRL bags behaved similarly, in that $\mathrm{N}_{2} \mathrm{O}$ accumulated only in the first small bag experiment, and by the time of the third small bag subsample, the water in both CTRL bags was consuming $\mathrm{N}_{2} \mathrm{O}$. The $\mathrm{CB}+\mathrm{B}+\mathrm{DFB}$ and $\mathrm{CB}+\mathrm{DFB}$ treatments were similar to each other and they all changed little or showed a net disappearance of $\mathrm{N}_{2} \mathrm{O}$. In other cases, duplicate 101 bags diverged, even when the duplicate small bags replicated well. For example in Fig. 4a (Expt BB 2), $\mathrm{N}_{2} \mathrm{O}$ in both sets of small bags decreased over the course of the experiment in 1 of the CB treat- 
ment $10 \mathrm{l}$ bags, but an increase in $\mathrm{N}_{2} \mathrm{O}$ in both sets of small bags sampled was observed at the second time point for the second $\mathrm{CB}$ treatment $10 \mathrm{l} \mathrm{bag.} \mathrm{All} 10 \mathrm{l}$ bags (except the control) in Expt BB 2 received cultured bacteria plus various combinations of $\mathrm{B}$ and $\mathrm{DFB}$. None of the treatments showed a consistent enhancement of $\mathrm{N}_{2} \mathrm{O}$ accumulation relative to the control.

In Expt BB 3 (Fig. 4b), 2 rather than 3 sets of small bag subsamples were taken due to time constraints, and $\mathrm{N}_{2} \mathrm{O}$ was measured in each small bag 2 or 3 times ( 1 and $6 \mathrm{~d}$ or 1,3 , and $5 \mathrm{~d}$ after acetylene addition). $\mathrm{N}_{2} \mathrm{O}$ accumulation was detected in 3 of the 4 small bags subsampled from the control treatment at the second time point (after $16 \mathrm{~d}$ incubation in the $10 \mathrm{l}$ bags). Of the 8 small bags subsampled from the DFB treatments, 7 showed $\mathrm{N}_{2} \mathrm{O}$ accumulation, as did 6 of the 8 small bags subsampled from the treatments that received cultivated bacteria, bactopeptone and DDC. Bags that received additions of HA showed more variable changes in $\mathrm{N}_{2} \mathrm{O}$ concentrations, in some cases appearing to consume $\mathrm{N}_{2} \mathrm{O}$ rapidly.

\section{DISCUSSION}

\section{West lobe}

The shape of the depth distribution of denitrification in the west lobe was consistent with predictions based on observed DIN profiles. Nitrate was present in the water column above $25 \mathrm{~m}$ but was undetectable at and below $25 \mathrm{~m}$. Denitrification was detectable only at depths where nitrate was present and not in the oxic layer shallower than $13 \mathrm{~m}$. The rate at $13 \mathrm{~m}$ was low and associated with high variability, but nonetheless supports the occurrence of denitrification where oxygen is still present in the water column.

Oxygen concentration is assumed to be a critical factor in determining whether denitrification is induced, so it is unfortunate that we were not able to measure oxygen at the time of our sampling. We interpreted the ammonium profile as an indication of the redox status of the water: ammonium concentration increased rapidly below $13 \mathrm{~m}$, indicating the depth of the oxycline in this region. Oxygen profiles were measured at the same sampling hole at approximately monthly intervals by the McMurdo LTER project. The closest LTER data are from November and December 1999, within days of our sampling, when oxygen was measured with a YSI meter on the CTD profiler. The YSI data for $16 \mathrm{~m}$ were $122 \mu \mathrm{M}\left[\mathrm{O}_{2}\right]$ (10 November 1999, $7 \mathrm{~d}$ prior to our sampling) and $109 \mu \mathrm{M}$ (6 December 1999, 20 d after our sampling). At $25 \mathrm{~m}$, the YSI recorded 38 and $31 \mu \mathrm{M} \mathrm{O}_{2}$ in November and December 1999, respectively. In culture and in seawater, the conventional cutoff for oxygen concentrations below which denitrifi- cation is expected to occur is variously reported in the range of 1 to $10 \mu \mathrm{M}$ (Hahn 1983, Zumft 1997). Because we detected denitrification at these depths, the Yellow Springs Instrument (YSI) values seem too high. One explanation may be that the water for incubations was taken from a greater depth, where $\left[\mathrm{O}_{2}\right]$ was lower. If this was the case, $\mathrm{NO}_{2}^{-}$concentrations, which increased rapidly with depth in this region, should be higher in our samples relative to the $\mathrm{NO}_{2}{ }^{-}$concentrations reported by the LTER team (at the same time as the YSI oxygen measurements for the sampling date closest to the date of our sample collection). A comparison of $\mathrm{NO}_{2}{ }^{-}$concentrations with those measured for our samples (LTER team/this study: $16 \mathrm{~m}\left[\mathrm{NO}_{2}^{-}\right], 177 / 157 \mu \mathrm{M} ; 25 \mathrm{~m}\left[\mathrm{NO}_{2}^{-}\right], 233.9 /$ $229 \mu \mathrm{M})$ ) shows that the LTER concentrations were higher. This implies that the LTER samples came from slightly deeper, not shallower, water than did the bag samples. It seems likely, therefore, that the $\mathrm{YSI} \mathrm{O}_{2}$ data are somewhat inaccurate, possibly because the probe was not calibrated at the in situ salinity and the instrument may not have equilibrated perfectly during the cast. Ammonium and nitrate concentrations were very similar between the LTER and incubation samples, which does not allow any inference about depth differences. We conclude, therefore, that the oxygen concentration in the lake and in the incubation bags was considerably lower than the YSI data imply. It is also possible that the oxygen 'cutoff', the concentration above which denitrification cannot occur or is not induced, is higher than that inferred from previous field and culture studies. Either way, oxygen concentrations in the west lobe were compatible with denitrification, based on the absence of oxidized nitrogen in the deep water and our detection of active denitrification in the bag incubations.

Because no nutrient additions (organic carbon or nitrate) were made to the incubation bags, the measured rates probably were not stimulated, but they may have been inhibited by perturbation of the samples and lengthy exposure to acetylene. The maximum measured rate of $\mathrm{N}_{2} \mathrm{O}$ accumulation would be equivalent to the reduction of $35.2 \mathrm{nM} \mathrm{d}^{-1}$ of nitrate. Given the in situ $\left[\mathrm{NO}_{3}{ }^{-}\right]$of $15.7 \mu \mathrm{M}$, this implies a turnover time of $446 \mathrm{~d}$ at $16 \mathrm{~m}$, a very rough estimate but useful for order of magnitude comparisons. Primary production is slow at this depth, but photosynthesis is generally detected at all depths above $20 \mathrm{~m}$ (LTER team). Therefore, denitrification is not the only sink for nitrate in this depth interval. Primary production measured at

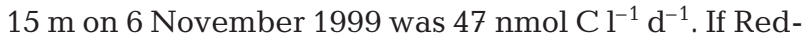
field stoichiometry is assumed, with $\mathrm{NO}_{3}{ }^{-}$supplying all of the $\mathrm{N}$ demand, this amount of $\mathrm{C}$ fixation implies the assimilation of $6.1 \mathrm{nmol} \mathrm{N}^{-1} \mathrm{~d}^{-1}$, and a $\mathrm{NO}_{3}^{-}$turnover time from assimilation of $2211 \mathrm{~d}$. Thus, it appears that denitrification could be the main sink for $\mathrm{NO}_{3}{ }^{-}$in this interval, and that the $\mathrm{N}$ cycle in general turns rather 
slowly. These rate estimates are compromised by the fact that the denitrification rates were measured at $12^{\circ} \mathrm{C}$, significantly higher than in situ temperatures (see below). The primary production measurements were made at in situ temperatures, so the relative contributions of the 2 sinks are probably more similar than implied by the values derived directly from the incubations.

\section{East lobe}

Based on the DIN profiles, it was expected that denitrification, if it were occurring in the east lobe, should be detected at depths $>19 \mathrm{~m}$, i.e. at the top of the nutricline, analogous to the west lobe, where ammonium concentration increased dramatically below $13 \mathrm{~m}$. On the other hand, the large and anomalous accumulation of nitrate in the suboxic waters of the east lobe hypolimnion implies the absence of denitrification altogether. The presence of $\mathrm{NO}_{3}{ }^{-}, \mathrm{NO}_{2}{ }^{-}$ and $\mathrm{N}_{2} \mathrm{O}$ in the deep waters of the east lobe and their failure to detect either $\mathrm{N}_{2} \mathrm{O}$ production or consumption in east lobe waters led Priscu et al. (1996) to suggest that nitrification must be responsible for the $\mathrm{N}_{2} \mathrm{O}$ buildup in the chemocline. However, nitrification could not be detected using nitrapyin as an inhibitor, and Priscu et al. (1996) concluded that conventional nitrification was not occurring at the time of the investigation. Given the great stability of the lake stratification (mixing occurs essentially at the molecular diffusion scale, requiring $50000 \mathrm{yr}$ to stir the lake; Priscu et al. 1996), these authors suggested that the $\mathrm{N}_{2} \mathrm{O}$ peak, and perhaps the depth distributions of $\mathrm{NO}_{3}{ }^{-}$and $\mathrm{NO}_{2}{ }^{-}$, might be fossil records of past metabolic activity, with little or no $\mathrm{N}$ cycling occurring below the chemocline in the present day.

In contrast, our experiments detected both $\mathrm{N}_{2} \mathrm{O}$ disappearance and production in the presence of acetylene. The biological meaning of $\mathrm{N}_{2} \mathrm{O}$ consumption is not clear; denitrification is the only process that consumes $\mathrm{N}_{2} \mathrm{O}$ of which we are aware, and that should have been inhibited in the presence of acetylene. Due to the high salt content, the effective concentration of acetylene was probably lower than intended and may not have been sufficient to fully inhibit denitrification. In this case, consumption of $\mathrm{N}_{2} \mathrm{O}$ would also be evidence for the presence of denitrification in the deep water. Some incubations, however, consistently produced $\mathrm{N}_{2} \mathrm{O}$ in the presence of acetylene. The rate data from the east lobe are not of the highest quality; replication suffered from the difficulty of equilibrating acetylene into water of such high ionic strength, and small differences in degassing during handling could lead to high variability in initial $\mathrm{N}_{2} \mathrm{O}$ levels and changes throughout the incubation. Nevertheless, the CIs for the slopes of $\mathrm{N}_{2} \mathrm{O}$ accumulation of replicate bags with blanks subtracted did not overlap with zero, and we conclude that denitrification occurred in samples collected from 19 and $25 \mathrm{~m}$. Depths greater than $25 \mathrm{~m}$ were not sampled, but in retrospect, deeper samples might be interesting and are required to define the distribution.

The highest rates of $\mathrm{N}_{2} \mathrm{O}$ accumulation in the east lobe were more than 10-fold faster than the highest rates detected in the west lobe. This is remarkable, given that denitrification has never before been detected in the east lobe. At $25 \mathrm{~m}$, the accumulation of $\mathrm{N}_{2} \mathrm{O}$ would correspond to the reduction of $442 \mathrm{nM}$ $\mathrm{NO}_{3}{ }^{-} \mathrm{d}^{-1}$ and imply a turnover time for the in situ $\mathrm{NO}_{3}{ }^{-}$ pool of $257 \mathrm{~d}$. The analogous calculation for $19 \mathrm{~m}$ in the east lobe yields a turnover time for the $\mathrm{NO}_{3}{ }^{-}$pool of 502 d. Although poorly constrained due to the large uncertainty in the rate measurement, these turnover times imply an $\mathrm{N}$ cycle as active in the east as in the west lobe. Rates in both lobes are probably overestimated due to the elevated incubation temperature (see below), but it is noteworthy that rates significantly greater than zero were detected in bag incubations from both lobes.

\section{Trace metal and nutrient manipulation experiments}

There were no entirely consistent treatment results that implied active denitrification from Expt BB 2 in 2000 (Fig. 4a). Some small bag time courses, subsampled from the large bag treatments, yielded positive rates of $\mathrm{N}_{2} \mathrm{O}$ accumulation; however, it was never the case that most of the small bags from both replicate large bags yielded consistently positive results. In Expt $\mathrm{BB} 3$, however, 2 treatments (DFB and $\mathrm{CB}+\mathrm{B}+\mathrm{DDC}$ ) yielded more consistent results, in that 6 or 7 of 8 small bags were positive, and the magnitudes of the accumulations were similar within treatments (Fig. 4b). The length of the treatment incubations in 2000 (3 wk) makes it impossible to interpret the computed $\mathrm{N}_{2} \mathrm{O}$ accumulation rates in terms of in situ denitrification rates (because of the likelihood of incubation artifacts caused by 3 wk incubations at elevated temperature). The rates are substantial, however, equivalent to or exceeding that measured at $25 \mathrm{~m}$ in 1999. This can be interpreted as evidence for the capacity of denitrification in this water, but offers little constraint on the actual rates that might be occurring in situ. Thus, there were no obvious effects of altering trace metal availabilities with the suite of chelators or dilution treatments used here. The high metal concentrations (Wells et al. unpubl.) suggest that toxicity is more likely than limitation, although the ratios of metals may be significant factors as well. Metals other than iron 
and copper, those preferentially targeted in the chelator treatments we used, may also be important, and effects due to them might not have been detected in these experiments.

\section{Oxygen considerations}

Because of the importance of oxygen in determining induction of denitrification, it is important to consider whether the accumulation of DIN in the east lobe could be due to inhibition of denitrification by $\left[\mathrm{O}_{2}\right]$ in excess of the level required to induce denitrification, or to allow complete denitrification to $\mathrm{N}_{2}$. Therefore, precise evaluation of the actual $\left[\mathrm{O}_{2}\right]$ in the lake and in the experimental incubations is important. The comparable LTER data are for the sampling depth of $25 \mathrm{~m}$, where $\left[\mathrm{O}_{2}\right]$ was $109 \mu \mathrm{M}$ in November and $47 \mu \mathrm{M}$ in December 1999. As for the west lobe, we can compare DIN concentrations to assess the potential depth differential between data collected in November at the nominative depth of $25 \mathrm{~m}$ in the east lobe (LTER team/this study: $\left[\mathrm{NO}_{3}^{-}\right], 133 / 114 \mu \mathrm{M}_{i}\left[\mathrm{NO}_{2}^{-}\right], 29.1 /$ undetectable $\left.\mu \mathrm{M}_{i}\left[\mathrm{NH}_{4}^{+}\right], 104 / 79 \mu \mathrm{M}\right)$. The higher nutrient concentrations imply that the LTER data were derived from slightly deeper sampling depths than were the incubation samples. The difference is probably due to the more accurate depth measurement by the pressure sensor on the CTD compared to our calibrated handheld line. Regardless of possible depth offsets, the reported oxygen values are probably higher than in situ concentrations, as discussed above for the west lobe. Even though we do not have good estimates of actual $\left[\mathrm{O}_{2}\right]$ in either lobe, it is noteworthy that the YSI values were similar at the putative denitrification depths in the 2 lobes. At $25 \mathrm{~m}$, the November and December 1999 YSI $\left[\mathrm{O}_{2}\right]$ values were lower in the west (38 and $31 \mu \mathrm{M}$ ) than in the east (47 and $109 \mu \mathrm{M}$ ) lobe, but denitrification was detected in east lobe water from $25 \mathrm{~m}$ and not in the west lobe at that depth. So, while accurate $\left[\mathrm{O}_{2}\right]$ determination would be very informative, oxygen does not appear to be the critical difference between the 2 lobes in terms of allowing or inducing denitrification. Oxygen was not measured in the incubation bags in 1999, but the microcolorimetric measurements in 2000 (see next paragraph) are perhaps our best estimates of $\left[\mathrm{O}_{2}\right]$ at the sample depths. Those values were lower than any reported in the YSI database.

LTER oxygen measurements are not available at present for 2000, but the long-term stability of the lake makes rough comparisons between data from 1999 and 2000 reasonable. In contrast to 1999, oxygen was measured directly in the incubation bags in 2000. The overall average measured in the $10 \mathrm{l}$ bags for both experiments was $32.5 \mu \mathrm{M}$, which is high compared to the putative denitrification threshold $\left[\mathrm{O}_{2}\right]$. However, it is substantially lower than that recorded in the lake by YSI measurement, and even lower than measurements recorded by Winkler titration for profiles collected at the same stations in 1994 and 1995 (LTER team). All the potential interferences, mechanics in sampling problems and analytical uncertainties in the microcolorimetric oxygen concentration measurements tend to increase the apparent $\left[\mathrm{O}_{2}\right]$, yet these are the lowest $\left[\mathrm{O}_{2}\right]$ data reported for the lake water. Thus, the best estimate of actual $\left[\mathrm{O}_{2}\right]$ in the bags is probably the direct microcolorimetric measurement, even though those measurements are somewhat variable (Fig. 3).

\section{Temperature considerations}

The denitrification rate data from incubation experiments in the east lobe are imprecise due to variability in behavior of replicate bags, but they nevertheless document the possibility that denitrifying bacteria were viable at the time of sampling and suggest that denitrification could be occurring at some level in situ. This is a surprising result, given past inability to detect denitrification and the large accumulations of nitrate and nitrous oxide in the east lobe. This result requires that we consider all possible sources of artifact that might yield apparent denitrification. If the measured denitrification rates are the result of microbial processes, the rates are unlikely to result from contamination by trace levels of organisms from another source. West and east lobe samples were never collected on the same dates, and the sample tubing was exhaustively cleaned with strong acids and detergents between sampling events, which were separated by up to several days. The large incubation bags were never reused, and the bags in which the depth profile incubations were performed in 1999 had never been used before.

Cultivated denitrifying bacteria previously isolated from the lake were present in the laboratory at the time the gear was assembled. It seems unlikely, however, that sufficient contamination could occur between sealed culture bags and the sampling equipment to produce the internally consistent depth profile observed. Moreover, similar experiments in which the CB were purposely added to water collected from below the chemocline in the east lobe never demonstrated an enhanced rate of bacterial production from added microbes. In other words, the CB were not able to thrive when introduced into the deep water, whereas they did show enhanced growth (assayed by ${ }^{3} \mathrm{H}$-thymidine incubations at $12^{\circ} \mathrm{C}$ ) when added to samples collected at $19 \mathrm{~m}$-within or above the chemocline (Ward et al. 2003). 
Alternatively, the in situ assemblage may have been stimulated by some perturbation induced by the incubation conditions. In order for incubation conditions to induce or stimulate denitrification by the resident community, denitrifying bacteria must have been present and viable at the time of sampling. We detected the presence of denitrifying bacteria in both lobes of Lake Bonney previously by immunofluorescence (Ward \& Priscu 1997); 2 strains, 1 originally isolated from $17 \mathrm{~m}$ in the east lobe (ELB17) and 1 isolated from $20 \mathrm{~m}$ in the west lobe (WLB20), were enumerated on several dates in 1993 and 1994 in both lobes. Both organisms were present in both lobes. Interestingly, ELB17 was present in an abundance maximum $\left(10^{4}\right.$ cells ml ${ }^{-1}$ ) centered around $17 \mathrm{~m}$ in the west lobe - in the depth interval where denitrification was measured as reported here-and was much less abundant at both shallower and deeper depths $\left(<10^{3}\right.$ cells $\mathrm{ml}^{-1}$ ). In the east lobe, ELB17 was rare in the surface layer $\left(<10^{3}\right.$ cells $\left.\mathrm{ml}^{-1}\right)$ and increased dramatically to $>10^{4}$ cells $\mathrm{ml}^{-1}$ at $17 \mathrm{~m}$, remaining at that high abundance down to at least $35 \mathrm{~m}$. Strain WLB20 showed a broad maximum of $>10^{4}$ cells $\mathrm{ml}^{-1}$ between 13 and $23 \mathrm{~m}$ in the west and was present at low levels $\left(\sim 10^{2}\right.$ cells $\mathrm{ml}^{-1}$ ) in the east lobe except for a maximum of $10^{4}$ cells ml ${ }^{-1}$ between 17 and $20 \mathrm{~m}$. The depth distributions of the 2 strains in the 2 lobes suggests different compatibilities with the chemical distributions or compositions of the 2 lobes, but each constituted a maximum of 2 to $5 \%$ of the total bacterial abundance enumerated by acridine orange direct counts, implying that the cultivated strains were significant components of the natural community. Although the enumeration data were collected some years previously, they imply that Strains ELB17 and WLB20 and perhaps many other denitrifying strains are current inhabitants of the lake. More recently, nirS genes (which encode the heme type nitrite reductase enzyme common in denitrifying bacteria) have been sequenced from samples collected below the chemocline in both lobes of the lake in 2000 (Francis \& Ward unpubl.). Thus, it is clear that absence of genetic or biochemical capability is not the reason for the apparent lack of denitrification in the lake.

No treatments were necessary in order to detect denitrification at 19 and $25 \mathrm{~m}$ in the east lobe depth profile experiments, and rates observed in the dilution experiments and BB experiments were of the same order, giving credence to the results. The only perturbation in the experiments, other than enclosure in the bags, was the incubation at $12^{\circ} \mathrm{C}$, which was $6^{\circ} \mathrm{C}$ higher than the highest temperature the community could have encountered in situ. The elevated temperature is essentially the only difference in experimental design between the experiments reported here and those reported previously (Priscu et al. 1996), which were carried out in $100 \mathrm{ml}$ glass syringes at in situ for $7 \mathrm{~d}$, also using the acetylene block method.

Growth experiments with the Isolates WLB20 and ELB17, as well WLB35 (isolated at the same time from $35 \mathrm{~m}$ in the west lobe), detected an optimal growth temperature of 12 to $15^{\circ} \mathrm{C}$ for all 3 isolates (Ward \& Priscu 1997). The shortest observed generation times were on the order of $40 \mathrm{~h}$ (at $12^{\circ} \mathrm{C}$ ). On the basis of growth experiments at several temperatures and salinities, it was estimated that the in situ generation times for the strains would be on the order of $100 \mathrm{~h}$. Based on growth rates at $12^{\circ} \mathrm{C}$ and the in situ temperature of the isolates $\left(6^{\circ} \mathrm{C}\right.$ for ELB17 and $-0.5^{\circ} \mathrm{C}$ for WLB20), a $Q_{10}$ of 3.94 can be calculated for ELB17 and 2.41 for WLB20. For estimation purposes, we assume these $Q_{10}$ values also apply to denitrification rate, and we apply the $Q_{10}$ for ELB17 to the rate measurements in the east lobe and the $Q_{10}$ for WLB20 to the west lobe. The temperature correction implies that the actual rates would have been reduced by about a factor of 3 in both lobes, from 9.22 to $2.8 \mathrm{nM} \mathrm{h}^{-1}$ in the east and from 0.733 to $0.26 \mathrm{nM}$ $\mathrm{h}^{-1}$ in the west lobe. The higher $Q_{10}$ for ELB17 implies greater temperature sensitivity in this strain, but does not extrapolate to total lack of activity at the in situ temperature. The temperature-corrected rates imply slower nitrate turnover times than those calculated above, but still support the potential for denitrification in both lobes of the lake. Of course, the potentially compounding effect of increased salt concentration and varying salt composition at greater depths (accompanied by colder temperatures) is not accounted for in the $Q_{10}$ calculation, and this could be an important factor in determining in situ rates.

The increased temperature during incubation periods of several days in which the denitrification rates were measured in the depth profile experiments may have been sufficient to increase the activity of the in situ population to the extent of producing detectable denitrification rates, while the rates at the in situ temperature and salt conditions might well have been essentially undetectable. Thus the most likely explanation for the DIN accumulation in the east lobe is that a barely viable denitrifying assemblage is present but that the conditions are inhospitable enough to prevent activity above maintenance level. Measurements of bacterial productivity in parallel samples implied the same: the deep waters of the east lobe are not a 'dead zone', but allow very slow bacterial metabolism. Higher temperatures in the incubation experiments stimulated the natural assemblage to activity levels that were detectable over long incubations. Exactly what aspects of the in situ conditions prevent growth and denitrification in the east lobe remains the subject of future investigations. 


\section{CONCLUSIONS}

Distribution of denitrification in the west lobe is consistent with that expected from the distribution of DIN and occurs at rates consistent with relatively slow overall N cycling in the lake. Denitrification is the main sink for nitrate below the photic zone, and is sufficient to explain the lack of nitrate in deep water.

Denitrification was detected for the first time in waters sampled from the east lobe of Lake Bonney. Although the measurements were associated with large uncertainties, non-zero rates were detected in multiple independent incubation experiments in separate years. Thus, we cannot conclude that denitrification is completely absent from the east lobe. It seems clear that the measured DIN accumulations in the east lobe are not consistent with the denitrification rates measured in the incubation experiments. We suggest the resolution of this discrepancy lies in the temperature sensitivity of the in situ population. While in situ conditions are not sufficiently hostile to prevent maintenance of a viable bacterial population, they do not allow significant denitrification, which was only detectable when the incubation temperature was raised to $12^{\circ} \mathrm{C}$. The denitrification results are consistent with our previously reported data on low, but consistently detectable, bacterial production in these same samples.

\section{LITERATURE CITED}

Boswell CR, Brooks RR, Wilson AT (1967a) Some trace elements in lakes of McMurdo Oasis, Antarctica. Geochim Cosmochim Acta 31:731-736

Boswell CR, Brooks RR, Wilson AT (1967b) Trace element content of Antarctic lakes. Nature 213:167-168

Broenkow WW, Cline JD (1969) Colorimetric determination of dissolved oxygen at low concentrations. Limnol Oceanogr 14:450-454

Bruland KW, Knauer GA, Martin JH (1979) Sampling and analytical methods for the determination of copper, cadmium, zinc and nickel at the nanogram per liter level in seawater. Anal Chim Acta 105:223-245

Byrne MD, Nicholas DJD (1986) Multiple-phase equilibration headspace analysis for the determination of $\mathrm{N}_{2} \mathrm{O}$ an $\mathrm{N}_{2}$ during bacterial denitrification. Anal Bioch 154:470-475

Coyne M, Arundkumari A, Averill B, Tiedje JM (1989) Immunological identification and distribution of dissimilatory heme cd1 and nonheme copper nitrite reductases in denitrifying bacteria. Appl Environ Microbiol 55: 2924-2931

Craig H, Wharton RA, McKay CP (1992) Oxygen supersaturation in ice-covered Antarctic lakes-biological versus physical contributions. Science 255:318-321

Granger J, Price NM (1999) The importance of siderophores in iron nutrition of heterotrophic marine bacteria. Limnol Oceanogr 44:541-555

Hahn J (1983) Nitrous oxide in the oceans. In: Delwiche CC (ed) Denitrification, nitrification and atmospheric nitrous oxide. John Wiley \& Sons, New York, p 191-242

Hobbie JE, Daley RJ, Jasper S (1977) Use of Nuclepore filters for counting bacteria by epifluorescence microscopy. Appl Environ Microbiol 33:1225-1228

Lee PA, Mikucki JA, Foreman CM, Priscu JC and 5 others (2004) Thermodynamic constraints on microbially mediated processes in lakes of the McMurdo Dry Valleys, Antarctica. Geomicrobiol J 21:221-237

Lizotte MP, Sharp TR, Priscu JC (1996) Phytoplankton dynamics in the stratified water column of Lake Bonney, Antarctica. I. Biomass and productivity during the winter-spring transition. Polar Biol 16:155-162

Lyons WB, Fountain A, Doran P, Priscu JC, Neumann K, Welch KA (2000) Importance of landscape position and legacy: the evolution of the lakes in Taylor Valley, Antarctica. Freshw Biol 43:3555-3567

Martinez JS, Haygood MG, Butler A (2001) Identification of a natural desferrioxamine siderophore produced by a marine bacterium. Limnol Oceanogr 46:420-424

Parsons TR, Maita Y, Lalli CM (1984) A manual of chemical and biological methods for seawater analysis. Pergamon Press, Oxford

Price NM, Harrison JG, Herring JG, Hudson R, J, Nirel PMV, Palenik B, Morel FMM (1988/1989) Preparation and chemistry of the artificial algal culture medium Aquil. Biol Oceanogr 6:443-461

Priscu JC (1995) Phytoplankton nutrient deficiency in lakes of the McMurdo dry valleys, Antarctica. Freshw Biol 34: $215-227$

Priscu JC (1997) The biogeochemistry of nitrous oxide in permanently ice-covered lakes of the McMurdo Dry Valleys, Antarctica. Glob Change Biol 3:301-315

Priscu JC, Spigel RH (1998) Physical limnology of the McMurdo dry valleys lakes. In: Priscu JC (ed) Ecosystem dynamics in a polar desert: the McMurdo dry valleys, Antarctica, Vol 72. American Geophysical Union, Washington, DC, p 153-188

Priscu J, Downes MT, McKay CP (1996) Extreme supersaturation of nitrous oxide in a poorly ventilated Antarctic lake. Limnol Oceanogr 41:1544-1551

Snedecor GW, Cochran WG (1967) Statistical methods. Iowa State University Press, Ames, IO

Takacs CD, Priscu JC (1998) Bacterioplankton dynamics in the McMurdo dry valley lakes, Antarctica: poduction and biomass loss over four seasons. Microb Ecol 36: 239-250

Voytek MA, Priscu JC, Ward BB (1999) The distribution and relative abundance of ammonia-oxidizing bacteria in lakes of the McMurdo dry valley, Antarctica. Hydrobiologia 401:113-130

Ward BB, Carlucci AF (1985) Marine ammonium- and nitriteoxidizing bacteria: serological diversity determined by immunofluorescence in culture and in the environment. Appl Environ Microbiol 50:194-201

Ward BB, Priscu JC (1997) Detection and characterization of denitrifying bacteria from a permanently ice-covered Antarctic lake. Hydrobiologia 347:57-68

Ward BB, Granger J, Maldonado MT, Wells ML (2003) What limits bacterial production in the suboxic region of permanently ice-covered Lake Bonney, Antarctica? Aquat Microb Ecol 31:33-47

Weand BL, Hoehn RC, Parker BC (1976) Trace element distributions in an Antarctic meromictic lake. Hydrobiol Bull 10:104-114

Zumft WG (1997) Cell biology and molecular basis of denitrification. Microbiol Mol Biol Rev 61:533-616

Submitted: December 29, 2003; Accepted: October 23, 2004

Proofs received from author(s): March 8, 2005 